\title{
SDF1 in the dorsal corticospinal tract promotes CXCR4+ cell migration after spinal cord injury
}

\author{
Vicki M Tysseling ${ }^{1 *}$, Divakar Mithal ${ }^{2}$, Vibhu Sahni ${ }^{1}$, Derin Birch ${ }^{1}$, Hosung Jung ${ }^{2}$, Abdelhak Belmadani²,
} Richard J Miller ${ }^{2}$ and John A Kessler ${ }^{1}$

The original article [1] was initially published with the following list of authors: Vicki M Tysseling, Divakar Mithal, Vibhu Sahni, Derin Birch, Hosung Jung, Richard J Miller, and John A Kessler. This author list is now corrected as follows: Vicki M Tysseling, Divakar Mithal, Vibhu Sahni, Derin Birch, Hosung Jung, Abdelhak Belmadani, Richard J Miller, and John A Kessler). Abdelhak Belmadani has been added as co-author to this corrected author list.

\section{Author details}

${ }^{1}$ Northwestern University's Feinberg School of Medicine, Department of Neurology, Chicago, IL 60611, USA. Northwestern University's Feinberg School of Medicine, Department of Molecular Pharmacology and Biological Chemistry, Chicago, IL 60611, USA.

Received: 20 April 2011 Accepted: 20 April 2011

Published: 20 April 2011

\section{Reference}

1. Tysseling VM, Mithal D, Sahni V, Birch D, Jung H, Miller RJ, Kessler JA: SDF1 in the dorsal corticospinal tract promotes CXCR4+ cell migration after spinal cord injury. Journal of Neuroinflammation 2011, 8:16.

\footnotetext{
* Correspondence: vmtysseling@u.northwestern.edu

'Northwestern University's Feinberg School of Medicine, Department of Neurology, Chicago, IL 60611, USA

Full list of author information is available at the end of the article
}

Submit your next manuscript to BioMed Central and take full advantage of:

- Convenient online submission

- Thorough peer review

- No space constraints or color figure charges

- Immediate publication on acceptance

- Inclusion in PubMed, CAS, Scopus and Google Scholar

- Research which is freely available for redistribution

Submit your manuscript at www.biomedcentral.com/submit
() Biomed Central 